\title{
From thick to thin regional identities?
}

\author{
Kees Terlouw
}

Published online: 29 May 2011

(C) The Author(s) 2011. This article is published with open access at Springerlink.com

\begin{abstract}
Regions and regional identity have become more important over the last decades. At the same time regions have become less discernable as distinct historically rooted spatial entities. Globalisation and the decline of collective identities through individualisation transform both this regional reality and how regions are conceptualised. This article analyses the shifts in types of regional identities used by regional administrations in an increasingly competitive environment. It uses the contrast between 'thick' traditional and historical rooted well-established regional identities, and 'thin' regional identities which are more transitory and focus more on economic competitiveness. These concepts are used to analyse the regional identity of regional administrations in Northwest Germany and the Netherlands. Hybrid regional identities combining a locally specific mix of thick and thin elements of regional identity, and which link up with regional identities at other relevant scales, appear to be the most effective regional identities for regional administrations facing the challenges of both globalisation and the decline in collective identities.
\end{abstract}

Keywords Regional identity - Websites - Thick and thin identities · Northwest Germany · Netherlands

K. Terlouw ( $\bowtie)$

Urban and Regional Research Centre Utrecht, Utrecht University, Utrecht, The Netherlands

e-mail: terlouw@geo.uu.nl

\section{Introduction}

The regional level has become more important over the last decades. The autonomy of administrative regions has increased and new forms of regional cooperation have emerged. The growing importance of regions is linked to the growing importance attached to regional identity in both the external competition for resources with other regions and the internal mobilisation of regional stakeholders. The increasing role of regions and regional identity coincides paradoxically with the decline of clearly distinguishable regions with an established identity in an increasingly interrelated and changeable world. This article examines the shift from 'thick' regional identities of traditional well established regions, to 'thin' regional identities of new regions which are more based on functional cooperation. This introduction elaborates on the growing importance of regions and regional identity. In the subsequent section we further discuss the concepts of 'thin' and 'thick' regional identity. The rest of this article applies these concepts in analysing different and changing forms of regional identity in Northwest European regions.

This growing importance and number of regions is linked to wider changes. The increased global competitive pressures eroded since the 1970s the centralised welfare state. Neo-liberal solutions were introduced to deregulate the economy and improve the competitiveness of companies on the world market. Decentralisation of political power was one 
instrument used to confront the challenges of globalisation. The transfer of social and economic responsibilities reduced the financial and regulatory burdens on the central state. The regional level was also assumed to be better suited to provide companies with tailor made conditions helping them to compete on the world market. New forms of relations between the different levels of government emerged. Not only the hierarchical administrative relations changed through decentralisation and European Integration, but also new cooperative relations of governance were formed with non-state actors. The combination of changing vertical relation and the growth of horizontal linkages constantly create new political spaces and an unsettled novel forms of statehood. New regional organisations constantly emerge and their membership, territory and aims frequently change. These new regions are mostly linked to specific policies. As policies are constantly adapted to changing political situations, the lifetime of these new regions is limited. Many disappear after a few years, or are transformed into other forms of cooperation (Brenner 2004; Healy 2006; Rodríguez-Pose and Sandall 2008; MacLeod and Jones 2001; Van Houtum and Lagendijk 2000; Keating 1998; Porter and Wallis 2002; Cox 1999).

Not only regions have become more important over the last decades, also their identity has become more important. Regionalism has become an important political force in regions like Scotland, Flanders, Catalonia and Northern Italy. But regional identity has also become important for all other administrative regions and new forms of regional cooperation in their communication with external and internal audiences. Regions compete with each other for attention and resources from the central state. These are not only established administrative regions, but also new types of regions based on the cooperation between administrative regions. Besides this administrative competition, regions also compete for private resources. There is a shift from managerialism to entrepreneurialism in urban and regional governance (Harvey 2001). Regions increasingly try to attract private investments from companies, new residents and tourists. Regional competitiveness has become an important topic in the policy discourses on state and regions. Academics tend to be more sceptical. Especially economic geographers stress that not cities or regions, but firms compete with each other (Boschma 2004; MacLeod and Goodwin 1999; MacLeod 2001b; Kitson et al. 2004). The discussions of regional competitiveness are dominated more by policy concerns than by academic investigation. The regional policy tail is wagging the analytical dog (MacLeod 2001a, p. 809). 'Policymakers everywhere have jumped onto the regional and urban competitiveness bandwagon' (Kitson et al. 2004, p. 991). A regional development industry has emerged which transformed these analytical concepts into policy facts. Regions are affected by globalisation and regional competitiveness not so much because these are real, but while they are acted upon (Lagendijk and Cornford 2000, p. 210). Regional competitiveness is an important policy framework developed at the national and international level within which regional administrations have to operate. Promoting as specific regional identity or brand has become a central concept for promoting local competitiveness. Government officials, policy makers and various commercial and non-commercial stakeholders are convinced that a coherent, strong and attractive place identity will help to promote the economic development of their city, region and/or country (Boisen et al. 2011).

Regions not only have to compete with other regions for external resources, they also need to mobilise support from regional stakeholders, like participating municipalities, local companies and inhabitants. While traditional administrative regions are based on hierarchical power relations, new forms of regional cooperation depend more on voluntary collaboration and coalition building. Communicating a distinct regional identity and spatial imagination to stakeholders outside the administration especially becomes important for generating support for the new plans of new forms of regional cooperation (Healy 2006; MacLeod 2001a). Regions can use different forms of identity for different groups of stakeholders. To attract new businesses, growth coalitions focus on their regional qualities which make them profitable sites for investments. In contrast, to mobilise popular support for these neo-liberal policies, they use ideologies focussing on the shared interests of the whole regional community within a territory, which are presented as more important than the conflicting interest between capital and labour. Regional growth coalitions thus use different identities to attract outside resources and mobilise internal support (Cox 1999). 
The strongest regional identities are those which have developed over generations within more or less distinct territories. These traditional regional identities are similar to national identities and have a strong mobilising power for large sections of the population. Although these traditional regional identities are still important in regions where regionalism has become an important political force, like in Flanders, Scotland and Catalonia, these forms of collective identity linked to fixed territories are undermined by processes of globalisation and individualisation, which not only undermine traditional identities but create other-thinner-forms of identities. The section below further discusses these differences between 'thick' and 'thin' regional identities. The long process during which traditional thick identities are created is discussed first. Then attention shifts to the decline of these thick forms of collective identities and the emergence of more fluid and thinner forms of identity. These are linked in a in an ideal typical distinction between thick and thin regional identities, which is subsequently used to analyse regional identities in the Netherlands and Northwest Germany.

\section{Thick and thin regional identity}

Traditional regional identities take-like national identities - many generations to develop. They are rooted in a long political history linked to the development of the nation state. Sometimes regions are more or less artificial constructions of the central state which over time develop a regional identity based on their political importance. Strong regional identities are however more frequently based on centuries old conflicts over the loss of political autonomy to the central state, like for instance in Catalonia and Scotland. Other conflicts within a nation state can also strengthen regional identities. Flanders regional identity is based on linguistic conflicts within the Belgian state. Long term conflicts over the spatial distribution of taxation and public spending can also boost regional identity.

Anssi Paasi's (1986, 1996) work on the institutionalisation of regions based on the interaction between four basic shapes of regions, is a clear and widely used model for analysing these long term processes through which regional identities are established. The territorial shape is the most tangible aspect of a region. It includes its borders and the way in which these were constructed in history. Physical regional characteristics like land use patterns also form this shape. The regional stereotypes based on its territorial shape and especially on the characteristics of its population, are a common source of the symbolic shape of a region. This place of the region in people's consciousness forms a regional identity. The institutionalisation of this symbolic shape of a region is not so much a spontaneous process, but is organised. The state and civil society constantly communicate this regional identity through for instance educational institutions and the mass media. Together with the political administration of the regional territory this is part of the institutional shape. The functional shape refers to the established role of a region in larger systems. These are based on for instance its economic ties with neighbouring regions, or its place in the administrative national hierarchy. When these four shapes interlock they reinforce each other and generate institutionalised regions with a strong regional identity.

These forms of identity are based on stable regional communities with collective identities which are passed on to the next generations. This is now undermined by the scaling up of social and economic relations. The position of regions in the international division of labour becomes more changeable. The rapidly changing functional shape of regions undermines regional institutionalisation. Transformations of the state organisation, through for instance the creation of new regions by changing administrative borders and the emergence of new forms of administrative cooperation, further undermine established regions. There is less and less time for regional identities to become established in the population. Globalisation also dramatically extends the reach of social networks. Together with the individualisation of society this transforms social networks and identity formation.'We replace the few depth relationships with a mass of thin and shallow contacts.' (Bauman 2004, p. 69). The small stable local networks in which individuals were bound together with multiple bonds of kinship, friendship, work, church and mutual care disappear. These social ties are still important for individuals, but these ties become more separated from each other. Individuals increasingly choose with whom they have what kind of relation. The bonds in these individual centred social networks 
are weaker and more changeable. These individual networks are larger than traditional networks and the overlap between these individual networks decreases. The stable collective network is broken up into many changeable individual networks. Individual choice, rather than collective conventions and spatial proximity now determine social networks (Blokland 2003; Bauman 2004, 2001). Liquefaction takes place of social frameworks and institutions. Stable collective identities are replaced by chosen, fluid and temporary individual identities. 'In the brave new world of fleeting chances and frail securities, the old-style stiff and non-negotiable identities simply won't do.' (Bauman 2004, p. 27). Discussing and communicating identities becomes more important while in the current phase of liquid modernity identities are undermined. Identities are sometimes temporarily fixed, but are lighter than tradition identities and can be changed more easily (Bauman 2004, pp. 13-46). Especially conflicts can temporarily strengthen communities. Shared identities are usually mobilised when interdependencies cause problems, like for instance economic restructuring affecting specific areas (Amin and Thrift 2002, p. 30; Savage et al. 2005, p. 56; Donaldson 2006). Despite the decline in the localised nature of social networks, residents are still in many ways interdependent. Living together in space makes them interdependent for their quality of life (Blokland 2003, pp. 78-79). Proximity, propinquity (Amin and Thrift 2002), or throwntogetherness (Massey 2005), are the basis of many temporary spatial identifications. Shared interests in a specific place and at a specific moment can create a new, but transitory, regional identity. The relation between identity and space, which has never been straightforward, is thus now further complicated through individualisation, migration, economic changes and political rescaling.

These new forms of transient regional identities emerge not only spontaneously, but are also intentionally created to mobilise support. Especially new forms of regional cooperation lack institutionalised power and depend more on voluntary support from regional stakeholders. Occasionally they can mobilise support based on existing established regional identities, but this is usually very problematic. First of all, established regional identities are now being undermined by globalisation and individualisation. Secondly, the spatial shapes of these new forms of regional cooperation hardly coincide with established regions. Thirdly, these new regions are so new and unstable that they don't have the time to institutionalise and develop a distinct traditional regional identity. Fourthly, the multitude of partially overlapping and competing new regions hinder the development of their identity. For instance the larger Dutch municipalities participate in dozens of different forms of regional cooperation. In contrast to historically grown and culturally based traditional regions with broad and stable identities fixed to a given territory, these new regions have more fluid identities linked to specific policies.

To better understand and analyse the relation between these fluid new forms of regional identity and the more traditional forms of regional identity we make an ideal typical distinction between traditional 'thick' and new 'thin' forms of regional identity. Weberian ideal types are analytical concepts which in their purity do not exist in the complex reality. Ideal types are not constructed to describe reality in its complexity, but to better understand the different mechanisms which form reality. Ideal types incorporate these different aspects in their logically pure form (Weber 1980).

Thin and thick are sometimes used as metaphors to characterise these changing social relations. Anton Zijderveld (2000) uses them to analyse the changing role of institutions and networks. 'Today thick, greedy and closed institutions, conditioned by a heavy handed, often religiously and magically tabooed, coercive tradition, have been superseded by thinner, more voluntary, more open, and looser institutions which in the behaviour of people are often alternated or temporarily suspended by flexible networks.' (Zijderveld 2000, p. 128). The distinction between thick and thin identity is also sometimes made. Thick identity is more based on a shared culture and community relations. Thin identity is more related to a specific problem and requires less direct involvement with other individuals. Thick identities have a normative aspect, while thin identities are more practical and utilitarian (Shelby 2005; Hinman 2003). Thick identities are more fixed and rooted in culture and history, while thin identities are more fluid and based on dialogue (Delanty and Rumford 2005, pp. 68-86).

The ideal typical opposition between thick and thin regional identities can also be linked to other 
differences between traditional and new regions. Jones and MacLeod (2004, p. 435) differentiate between spaces of regionalism and regional spaces. Spaces of regionalism are culturally based political movement which want to increase the political autonomy of traditional territories. Regional spaces are the institutional context which influences regional economic development. Thick regional identities value the region as a political goal in itself, while thin regional identities are more based on a utilitarian legitimation of the effectiveness of especially economic policies. Thin regional identities are more functional and linked to sectoral policies and special interests, while thick regional identities are more integrative. Balancing the different interests of all inhabitants of a territory and integrating different policies in a given territory is based on sharing a stable thick regional identity. Thin regional identities focus on only a few, mostly economic characteristics, while thick regional identities cover a broad range of cultural, social, political, environmental and economic characteristics. Table 1 gives an ideal typical overview of the differences between thick and thin regional identities.

Thick and thin regional identities are ideal typical analytical concepts used to distinguish between fundamentally different aspects of regional identities. In reality regional identities combine thick and thin elements. Many traditional established regions, like Catalonia and Scotland, link their thin future oriented

Table 1 The difference between thick and thin regional identities

\begin{tabular}{lll}
\hline ASPECT & $\begin{array}{l}\text { Ranging from } \\
\text { thick }\end{array}$ & To thin \\
\hline Spatial form & $\begin{array}{l}\text { Closed } \\
\text { Territorial }\end{array}$ & Open \\
Network \\
Participants & General population & Administrators and \\
& Broad and many & Single \\
Purpose & Culture & Economy \\
Time & Defensive & Offensive \\
& Historical oriented & Future oriented \\
& Stable & Change \\
& Old & New \\
Scale focus & Local and National & Global \\
\hline
\end{tabular}

Source Terlouw (2009) regional identity with a thick identity rooted in history. Newer forms of regional cooperation, like the Ruhr area or the Randstad, try to thicken their thin economic regional identity by referring to the glorious past before the administrations in these regions started to cooperate. They do this to widen their support base and legitimation from policy makers to the general population (Terlouw 2010). Regional administrations sometimes use different regional identities for different audiences. Thin regional identities focussing on economic competitiveness are used to attract outside investors, while thick regional identities are used to conceal the drawbacks of these neoliberal policies for the general population by using an ideology which focuses on the shared interest of all members of a territorial community (Cox 1999).

\section{Thick and thin regional identities on websites}

One way to study the use of thick and thin regional identities is to examine how regional administrations present themselves to the outside world. Websites are well suited to communicate a clear identity. The regional authorities are in complete control of this medium which is easily accessible for a wider public. Through their hierarchical and selective nature websites can also structure complex information (Florek et al. 2006, p. 277; Urban 2002; Esrock and Leichty 2000). The selection of regional characteristics by regional administrations to communicate a regional identity to the outside world reflects only the official version of the regional identity.

We studied websites of regional administrations in the Netherlands and Northwest Germany. We studied the regional level just above the municipal level. Websites of regional administrations concentrate on external audiences and regional competitiveness (Dijkink and Winnips 1999; Fortin and Sanderson 2003). Municipal websites have a different character and are in general dominated by information for the local inhabitants (Jeffres and Lin 2006; Conroy and Evans-Cowley 2006). We therefore excluded the websites of the large German cities. We studied the 67 regional administrations one level above the municipal level. These are provinces in the Netherlands and districts (Kreise) in Germany. Only for the Ruhr area we used the website of the Regionalverband Ruhr. 
We analysed the home pages and the pages directly linked to the homepages. The structure of websites makes the opening page a shop window for the entire region. This opening page is especially important while the internet is a pull medium where users actively seek information (Florek et al. 2006, pp. 277, 281; Kolbe, 2007; McMillan 2000). Given the hierarchical structure of websites, we assume that the information presented in these top pages mirror the importance regional administrations attach to this information. We developed our coding scheme by first exploring about a dozen of German and Dutch websites. Table 2 gives an overview of the coding scheme used to determine the presence and prominence of items which are characteristic of thick or thin regional identities. Like many other studies we coded the presence of these aspects on websites, while the presence or absence of specific items minimizes subjective judgements (McMillan 2000). We limited our analysis to the official websites and did not consider other regional websites. The websites were visited in February 2008.

Table 2 Items on websites classified in relation to thin and thick regional identities

\begin{tabular}{lc}
\hline Items related to & Frequency \\
\hline Thick regional identity & 164 \\
Environment is a distinct theme & 38 \\
Environment is a dominant theme & 6 \\
Regional history or culture are distinct themes & 42 \\
Regional history or culture are dominant themes & 7 \\
Landscape or nature are distinct themes & 30 \\
Landscape or nature are dominant themes & 7 \\
Thin regional identity & 193 \\
Transport is a distinct theme & 34 \\
Transport is a dominant theme & 2 \\
Emphasize central location in country & 24 \\
Attract external companies & 31 \\
Attract visitors & 29 \\
Emphasize cooperation with non-neighboring & 2 \\
regions & \\
Link to European Union & 23 \\
Information on European Union & 21 \\
Emphasize central location in Europe & 12 \\
Link to foreign regions & 7 \\
Information on foreign regions & \\
\hline
\end{tabular}

Figure 1 shows the diverse use of thick and thin regional identity by different regions. It shows that almost all regions mix to some degree thick and thin items. Especially the regional identity of many more peripheral regions in the east is based on thick aspects. In contrast many more urbanised and more developed core regions like Hannover, the Ruhr area and Utrecht and Gelderland present a predominantly thin regional identity. The same is true for many regions neighbouring the large cities of Bremen and Hamburg in Northern Germany. An exploratory analysis of the correlations between these two types of regional identity and some background variables on regional development in the ESPON (2006) database only revealed strong significant correlations between indicators of regional development and the use of thin regional identities. There is in particular a strong relation between the use of aspects related to a thin regional identity and low unemployment rates (Pearson correlation coefficient $=-.413$ ). Thus economically strong regions with low unemployment rates predominantly use a thin regional identity.

Let us take a closer look at the regional identity formation of some of these regions. The region Hannover communicates a very strong thin regional identity on their website (see Fig. 1). Hannover is also the newest region studied here. The Region Hannover was created in 2001 on the territory of the city of Hannover and its surrounding region (Kreis Hannover). It took over all administrative functions of this old district (Kreis) and of its predecessor the Kommunalverband Großraum Hannover in which the old district cooperated with the city of Hannover. In addition it took over some administrative functions of both the city of Hannover and the federal state Niedersachsen. The Region Hannover is responsible for spatial planning, public transport, economic development, health care, education, housing and social services (www.hannover.de). As a recently created region with a limited range of duties, the Region Hannover quite understandably focuses on a thin regional identity. Presenting a thick regional identity would also be difficult while it has to deal with conflicting established identities. The established urban identity of the city of Hannover and the more traditional rural identity of its surrounding area are quite different.

Figure 1 shows that the province of Gelderland has the largest share of thin elements on its website for 
Fig. 1 The importance of thick (dark red) and thin (light green) regional identity (the size of the pie charts indicate the total number of identity relates items on the websites. See also the list of abbreviations of these regions in Table 3 in the Appendix)

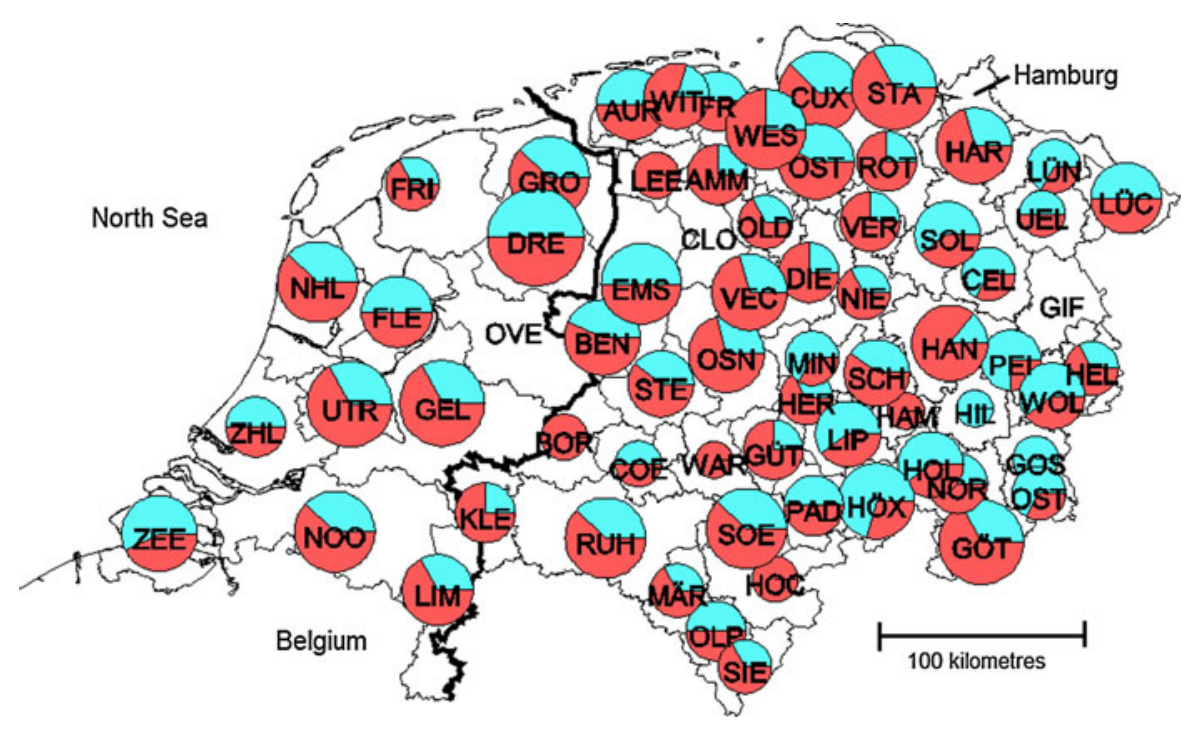

the Netherlands. This strong thin identity of the Dutch province of Gelderland can be explained from its history. Its name and much of its territorial shape date back to the Middle Ages when it was between 1096 and 1543 an independent Duchy. During the Dutch revolt against the Habsburg Dynasty it lost some territories but the main part of Gelre became as the province Gelderland part of the Netherlands (Noordzij 2008). Its borders have remained more or less the same until the present day. It not only lost its political independence in the sixteenth century, but also became a military buffer protecting the Dutch core area along the coast. Despite this long history, Gelderland has not developed a strong thick identity. It is difficult to develop a regional identity on a history of political failure. The regional diversity within its borders has also hindered the development of a traditional regional identity at the provincial level (Stinner and Tekath 2003). The areas within Gelderland range from rural peripheral Eastern border regions like the Achterhoek, to strongly urbanising areas in its Northwest, which is now becoming part of the Randstad; the highly urbanised core area of the Netherlands. But there are many other differences, like for instance between the urbanised area of the cooperating cities Arnhem and Nijmegen and the empty touristic region Veluwe. Each of these regions and cities has its own thick identity which hinders the development of a thick regional identity at the provincial level. The current provincial administration focuses therefore on a thin identity based on its intermediate position connecting the large urban regions of the Randstad and the Ruhr area. This intermediate position combined with suburbanisation from the Randstad has made Gelderland into one of the most economically successful regions in the Netherlands with the third lowest unemployment rate in our study area (ESPON 2006).

These short analyses of the background of these different forms of regional identities not only show the importance of the historical roots for the development of a regional identity, but also that regional identities are linked to spatial identities at other scales. In the next section we discuss in more detail the establishment of Lippe's thick regional identity in relation to its political context. The disadvantages of such a strong thick regional identity in the current competitive context are subsequently discussed in our analysis of the recently formed region OstWestfalenLippe to which Lippe belongs. Lippe's strong thick regional identity hinders its participation in this new region focussing on innovation.

\section{Stuck in a thick regional identity: Lippe}

Lippe, a region in the north-east of the German federal state of Nordrhein-Westfalen has a very strong traditional regional identity. Historic buildings, landscape and the statue of Hermann, the German victor over the Roman legions, dominate the website of the Kreis Lippe (www.lippe.de). Lippe has 
been an independent German state in almost the same borders from the Middle Ages to the formation of the German state in 1871. It was one of the federal states until the Second World War. It is now an administrative district with a stronger identity and more administrative resources than its neighbours. However, at the end of this section it will become clear that this well established regional administration and thick regional identity are now threatened by the rescaling of the German state.

Lippe's political success in defending its independence hindered for a long time its economic development. Whereas its neighbours became in the nineteenth century part of Prussia and industrialised, Lippe stagnated (Ellwein 1993, p. 265; Rinne 1993, pp. 67-72; Richter 1995, p. 284). This lack of regional development made Lippe into an iconic authentic German region or Heimat. This linked Lippe's regional image and identity with the German national identity at that time. In 1908 the nationalistic regional elite founded the Lippische Heimatbund to protect the authentic German region Lippe against the threats of modernisation. Especially industrialisation and urbanisation threatened the landscape and the traditional identity of the population. The policy of the Lippische Heimatbund to plant an oak in the birth village of each soldier from Lippe killed in the First World War, exemplifies the link between the German nation and the Heimat Lippe. This conceptual link was further strengthened by the Nazi's. After the Second World War the Lippische Heimatbund did not wither away, but increased its membership to about a tenth of the population. It decoupled the regional identity of Lippe from German national identity. The focus of its publications and its activities shifted to the particularities of its regional history and the protection of landscape and the environment (Stich 1998). This strengthened the inward focus of Lippe's regional identity.

Lippe lost its status as a federal state after the Second World War and was divided into two administrative districts. However, it obtained important concessions from the new federal state of Nordrhein-Westfalen (Ellwein 1997; HL 1999). First of all, Detmold, the old capital of Lippe, became the new administrative centre for the new province Regierungsbezirk Detmold. Secondly, it inherited the properties of the old state of Lippe. This was administered by local politicians through the
Landesverband Lippe and used for the benefit of the population of Lippe, through for instance subsidising regional cultural institutions. Its focus has shifted from funding urban cosmopolitan urban culture, like the Landestheater Detmold, to communicating the historically grown rural regional identity to the population. It founded for this purpose in 1971 the Institut für Lippische Landeskunde (HL 1999, p. 194). These activities are financed by the profits from the investments of the Landesverband Lippe in new housing estates and medical facilities in health spas.

The administrative and territorial reforms of the 1970s at first threatened Lippe. The planned scaling up of the provinces (Regierungsbezirke) would rob Detmold of its administrative functions. Lippe was also supposed to cede many villages to the neighbouring towns of Bielefeld and Herford. This external threat further strengthened the already strong regional identity of the population of Lippe. The population could thus be easily mobilised by Lippe's political elite to successfully avert these threats. They even succeeded in uniting the traditional territory of Lippe into one new administrative district (Ellwein 1997). This territorial reunification and strengthening of its institutions further strengthened its thick regional identity.

Lippe is an established region based on a territorial shape formed already in the late Middle Ages and which has hardly changed over the centuries. Its institutional shape is also strong. Even after its incorporation into Nordrhein-Westfalen it retained some of its institutions which it used to strengthen its institutional and territorial shape in the 1970s. It symbolic shape has only become stronger over the years and has focussed more and more on a thick regional identity. Its functional shape was more problematic while it did not industrialise like its neighbouring Prussian regions. Lippe's economy profited after the Second World War from the 'white industry' of the health spa's funded by the German welfare state. It however suffers in these last decades from the reductions in welfare spending by the German state, which decimated the funding of visits to health spas. This created huge financial difficulties for the Landesverband Lippe which is an important stakeholder in health spas, and which was subsequently forced to reduce their funding of Lippe's regional culture. More recent regional reform initiatives further undermine Lippe. The federal state of 
Nordrhein-Westfalen will gradually reduce the number and competences of its provinces (Danielzyk and Wood 2004). This already reduces the importance of the administrative centre in Detmold, which is scheduled to disappear altogether. Its competences are eroded by new forms of regional cooperation (see next section). Paradoxically this very well established region with a thick regional identity is not very well equipped to cope with the challenges of the rescaling German state. The focus of its economy on health spas, which helped its regional economic development during the welfare state, now causes economic problems because of the reductions in welfare spending by the German state. Furthermore, its thick regional identity with its territorial and inward historical focus hinders it to effectively participate in regional initiatives which are more open, networked, future oriented and focussed on economic competitiveness.

\section{Creating a thin neo-liberal economic regional identity: $O W L$}

In Bielefeld, a large city close to Lippe's borders, important regional companies like Bertelsmann together with the regional chambers of commerce of Bielefeld and Lippe founded in 1989 an association to promote the region Ostwestfalen-Lippe as a business location. As its complicated name suggests Ostwestfalen-Lippe has no clear established regional identity. First of all Lippe is very different from the rest. The previous section discussed its strong regional identity which distinguishes it from its neighbours. Ostwestfalen-Lippe also wants to communicate a regional identity which is different from the more rural Westfalen as a whole and the nearby declining Ruhr area. By stressing its many mid-sized cities with thriving local companies, they want to communicate that $O W L$ has a distinct and modern regional identity in Nordrhein-Westfalen. The communicated regional identity is thus based on economic issues, is offensive and future oriented (www. ostwestfalen-lippe.de).

In 1993 the private initiative was transformed into a Public Private Partnership. The regional administrations (Kreise) became equal partners in the newly formed OstWestfalenLippe Marketing $\mathrm{GmbH}$ with its offices in Bielefeld. The OstWestfalenLippe Marketing $\mathrm{GmbH}$ focuses its communication not on its own population, but on entrepreneurs. The level of regional identification of the population is much weaker than in Lippe. Initially it focussed on attracting investments from companies outside $O W L$, now it focuses more on improving the relations between local entrepreneurs. The communicated regional identity shifted from correcting a negative image, to promoting $O W L$ as an innovative and cooperative business community showing the rest of Germany how to improve global competitiveness through networking and deregulation (www.netswork.info; www.bertelsmann-stiftung.de; www.ostwestfalen-lippe.de; Danielzyk and Wood 2004).

Besides many business to business networks there is also an important network focussed on employment. In this Initiative für Beschäftigung $O W L$ local businesses, trade unions and policy makers from different administrative levels cooperate to improve the regional labour market through innovative ideas and training programs. It started in 1999 as an initiative of the Bertelsmann Foundation. This foundation owns the majority of the shares of the huge media conglomerate of Bertelsmann. This third largest media concern in the world has huge international interests in printed and electronic media (RTL). It subsidiary Arvato provides administrative services to companies and governments. In the United Kingdom it has even taken over part of the financial administration and social services of the municipalities of East Riding and Sefton (Weernicke and Bultmann 2007, p. 291; www.arvatogov.co.uk). Bertelsmann not only profits from deregulation, but the Bertelsmann Foundation also actively promotes neo-liberalism. In the opinion of Reinhard Mohn, who founded the Bertelsmann Foundation in 1977, there is too much state involvement in economy and society. He wanted the Bertelsmann Foundation to promote new relations between state, society and its citizens through decentralisation, networking and competition (Weernicke and Bultmann 2007, pp. 295-303; Schuler 2010). This initiative for employment in $O W L$ is one of many more similar projects initiated by the Bertelsmann Foundation. After 3 years running it, the Bertelsmann Foundation transferred in 2002 the management of this employment initiative to their regional partners and it operates now under the auspices of the 
OstWestfalenLippe Marketing GmbH. This did not end the involvement of the Bertelsmann Foundation in the regional networking in Ostwestfalen-Lippe. Following its own study on the economic potential of $O W L$ published in 2003, which showed the low degree of internationalisation of the regional economy, the Bertelsmann Foundation initiated a number of projects. It started for instance the Forum.Ost programme which is part of the EU aided EQUAL II project. This helps especially local SME's in $O W L$ to export to Central and Eastern Europe (www. bertelsmann-stiftung.de).

The OstWestfalenLippe Marketing GmbH creates not only new regional spaces outside the traditional administration through its networking activities. It is also more directly involved in the rescaling and deregulation of the German state. In 2002 the OstWestfalenLippe Marketing $\mathrm{GmbH}$ took the initiative together with its partners in its many networks to deregulate the regional economy. Funded by the federal state Nordrhein-Westfalen they developed detailed proposals to simplify economic regulations. In 2004 they were selected as a model region for the project Innovationsregionen in which the Bertelsmann Foundation cooperates with the ministry of trade and commerce in Berlin. All levels of government cooperate with different business interests in this project to stimulate global competitiveness by reducing bureaucracy and regulation. This business focussed administration initiative has created a new regional identity of $O W L$, which it proudly communicates to the outside world. Although its populations hardly identifies with $O W L$, the self-esteem of the population is somewhat strengthened by the reports in the media on the relative economic success of the firms in this backwater of Nordrhein-Westfalen. OWL is now also used as a best practice example in a federal government's image campaign. Other German regions are now starting to follow $O W L$ 's example (www.ostwestfalen-lippe.de).

The evolution of the cooperation in $O W L$ increasingly strengthens a thin regional identity, which is successfully communicated to the outside world. This thin identity could easily disappear. The wider adoption of administrative innovations spearheaded in $O W L$ and generating a strong future oriented but thin regional identity could spread this regional identity so much, that it is no longer a special characteristic of the region $O W L$.

\section{Mixing thick and thin regional identity: Emsland}

The Emsland presents itself on the internet with a regional identity based on a balanced mixture of thick and thin elements (see Fig. 1). The regional identity of the Emsland has changed over the last half century from a very thick and quite negative regional identity of a peripheral region in Germany, to a positive regional identity which mixes traditional thick rural elements with new thin elements based on its economic success and competitive position in Europe.

The Emsland was until the 1950s represented as the opposite of modern Germany. Reports focussed on its remote and barren landscape. Its inaccessible parts like the Hümmling were for centuries a refuge for outlaws and Gipsies (Knottnerus 1992, p. 37; Nauhaus 1984). Combined with the unproductive landscape, riddled with bogs, heaths and sand drifts and almost without villages, this engraved a negative image of the Emsland in the German collective consciousness. The increase in poverty after the demise of the local cottage industry in the nineteenth century further strengthened the negative image of the Emsland as the iconic German periphery, waiting to be developed through modernisation (Hucker et al. 1997, p. 348; Knottnerus 1992; Niehoff 1995). The regional identity of the Emsland was until the 1950s based on its negative image in Germany. It lacked at that time a regional administration. The spatial identity of the population focussed then more on either their smaller village communities or on their very strong Catholic identity which is linked to the much larger old clerical territories of the Bishops of Münster and Osnabrück.

The modernisation of the Emsland and its regional identity started in earnest after the Second World War. The poverty of its population compared to the rest of West Germany became problematic for the developing German welfare state whose legitimacy and identity was based on equalising the living conditions for the whole of the population (Brenner 2004). Developing the Emsland was the first important regional policy initiative in West Germany (Nauhaus 1984; Schüpp 1992). The German state stimulated the development of the Emsland through the establishment in 1951 of the Emsland GmbH in which all levels of the German state cooperated. These were eight districts around the Ems (about 
twice the size of the present Kreis Emsland), Niedersachsen and the central government, which provided most of the one billion Euros spend over the decades by the Emsland GmbH. Through integrated 10 -year-plans it improved infrastructure, soils, drainage, reorganised agricultural plots, cultivated new lands and afforested the worst soils. In total the Emsland $\mathrm{GmbH}$ restructured about a fifth of Emsland's surface and transformed most of the spatial elements linked to the traditional negative regional identity of the Emsland. The Emsland lost a lot of its specific characteristics and became more like the rest of rural Germany (Nauhaus 1984; Niehoff 1995; Schüpp 1992).

For the new administrative district Emsland created in 1977 this economic development became an important part of its regional identity. They frequently stress that the Emsland is no longer 'the poorhouse of the nation' but had over the last decade one of the highest regional economic growth rates in Germany. It is no longer an isolated peripheral region at the German border, but an accessible and competitive region in the hearth of Europe (www.emsland.de ). This is based on local SME's in the industrial sector. Whereas after the Second World War agriculture dominated economic policies and its regional identity, the industrial sector is now a more important economic sector than in Niedersachsen as a whole. The economy is diversified with an emphasis on metalworking and machine building. Many supply the Meyer shipyard which is the most important company in the Emsland and is one of the leading cruise ship builders in the world. This family company, its workers and its suppliers are strongly embedded in the catholic Emsland. Even though its inland river location is not suited for building ocean going cruisers, it refuses to relocate to the nearby deep water port Emden which has many, mostly abandoned, large shipyards but also has a protestant and social-democratic population. Instead it used its political influence on the government of Niedersachsen to deepen the Ems and to construction of a flood barrier which can temporarily raise the level of the Ems enabling new large cruise ships to travel from Papenburg to the North Sea (Niedersachsen 2007; Niehoff 1995; Schüpp 1992).

The regional identity communicated by the regional administration of the Emsland is based on not only on thin elements, like its economic performance rooted in regional networks of its competitive companies like the Meyer shipyard. It is equally based on its idyllic rural landscape with room for recreation and suburban housing. The old unproductive wastelands are now revalued focussing on its natural beauty and recreational potential. This mix of thick and thin elements created a strong regional identity which for instance helped to mobilise political support for the infrastructural measures discussed above to keep the successful Meyer shipyard in the region.

\section{Conclusion}

The distinction between the old traditional thick regional identities, with strong historic roots, and the new thin regional identities, which are more network based, fluid and future oriented, was very useful in analysing the formation and use of regional identities by regional administrations. By using it not as a dichotomy, but as at the ends of a continuum and by unfolding this typology into different aspects, it was a useful tool to compare the composition of different regional identities. Figure 1 and the case studies reveal the interplay between thick and thin forms of regional identity. Regional administrations use to different degrees both forms. For stimulating economic development they focus more on thin elements, while thick aspects of regional identity are used to mobilise support among the inhabitants. The regional identity communicated by regional administrations does not fit neatly in the ideal typical distinction between thick and thin forms of regional identity. But this ideal typical distinction helped us to better analyse how regional administrations try to accommodate different and partly contradictory political goals. Depending on the specific circumstances and history, regional administrations combine specific thick and thin elements. The discussion of the Emsland and Lippe showed that traditional thick regional identities can be used to different ends. While in the Emsland thick and thin aspects of regional identity were amalgamated into a single strong hybrid regional identity, Lippe is stuck in its thickening identity, and has difficulty to link up with the new dynamic thin identity emerging at a higher regional scale in $O W L$.

Regional identities change over time. Although thin regional identities are generally on the rise, the relation with aspects of a thick identity is important 
for legitimating competitiveness oriented policies. This strategic linking of thin and thick elements in the regional identity communicated by the different regional administrations builds on, but is not determined by their historical roots and context. Hybrid regional identities, which combine a locally specific mix of thin and thin elements of regional identity and which are able to link up with strong regional identities at other relevant scales, appear to be the most effective regional identities. Further research is however needed to determine what the best strategies are to link different thick and thin elements, how these relate to internal regional characteristics and to what extent these are linked to the larger areas to which a region belongs.

Open Access This article is distributed under the terms of the Creative Commons Attribution Noncommercial License which permits any noncommercial use, distribution, and reproduction in any medium, provided the original author(s) and source are credited.

\section{Appendix}

See Table 3.

Table 3 Abbreviations and websites of the regions in our study area

\begin{tabular}{|c|c|c|}
\hline AMM & Ammerland & http://www.ammerland.de/ \\
\hline AUR & Aurich & http://www.landkreis-aurich.de/ \\
\hline BEN & Bentheim & http://www.grafschaft-bentheim.de \\
\hline BOR & Borken & http://www.kreis-borken.de/ \\
\hline CEL & Celle & http://www.landkreis-celle.de/ \\
\hline CLO & Cloppenburg & http://www.lkclp.de/ \\
\hline $\mathrm{COE}$ & Coesfeld & http://www.kreis-coesfeld.de/ \\
\hline CUX & Cuxhaven & http://www.landkreis-cuxhaven.de/ \\
\hline DIE & Diepholz & http://www.diepholz.de/ \\
\hline DRE & Drenthe & http://www.drenthe.nl/ \\
\hline EMS & Emsland & http://www.emsland.de/ \\
\hline FLE & Flevoland & http://provincie.flevoland.nl/ \\
\hline FR & Friesland & http://www.friesland.de/ \\
\hline FRI & Friesland & http://www.fryslan.nl/ \\
\hline GEL & Gelderland & http://www.gelderland.nl/ \\
\hline GIF & Gifhorn & http://www.gifhorn.de/ \\
\hline GOS & Goslar & http://www.landkreis-goslar.de/ \\
\hline GOT & Göttingen & http://www.landkreis-goettingen.de/ \\
\hline GRO & Groningen & http://www.provinciegroningen.nl/ \\
\hline GUT & Gütersloh & http://www.kreis-guetersloh.de/ \\
\hline HAM & Hameln-Pyrmont & http://www.hameln-pyrmont.de/ \\
\hline HAN & Hannover & http://www.hannover.de/ \\
\hline HAR & Harburg & http://www.landkreis-harburg.de/ \\
\hline HEL & Helmstedt & http://www.helmstedt.de/ \\
\hline HER & Herford & http://www.kreis-herford.de/ \\
\hline HIL & Hildesheim & http://www.landkreishildesheim.de/ \\
\hline $\mathrm{HOC}$ & Hochsauerlandkreis & http://www.hochsauerlandkreis.de \\
\hline HOL & Holzminden & http://www.landkreis-holzminden.de/ \\
\hline $\mathrm{HOX}$ & Höxter & http://www.kreis-hoexter.de/ \\
\hline KLE & Kleve & http://www.kreis-kleve.de/ \\
\hline LEE & Leer & http://www.landkreis-leer.de/ \\
\hline LIM & Limburg & http://www.limburg.nl/ \\
\hline
\end{tabular}


Table 3 continued

\begin{tabular}{|c|c|c|}
\hline LIP & Lippe & http://www.lippe.de/ \\
\hline LUC & Lüchow-Dannenberg & http://www.luechow-dannenberg.de/ \\
\hline LUN & Lüneburg & http://www.lueneburg.de/ \\
\hline MAR & Märkischer Kreis & http://www.maerkischer-kreis.de/ \\
\hline MIN & Minden-Lübbecke & http://www.minden-luebbecke.de/ \\
\hline NIE & Nienburg & http://www.lk-nienburg.de/ \\
\hline NOO & Noord-Brabant & http://www.brabant.nl/ \\
\hline NOR & Northeim & http://www.landkreis-northeim.de/ \\
\hline NHL & Noord Holland & http://www.noord-holland.nl/ \\
\hline OLD & Oldenburg & http://www.oldenburg-kreis.de/ \\
\hline OLP & Olpe & http://www.kreis-olpe.de/ \\
\hline OSN & Osnabrück & http://www.landkreis-osnabrueck.de/ \\
\hline OSTH & Osterholz & http://www.landkreis-osterholz.de \\
\hline OSTR & Osterode & http://www.landkreis-osterode.de/ \\
\hline OVE & Overijssel & http://provincie.overijssel.nl/ \\
\hline PAD & Paderborn & http://www.kreis-paderborn.de/ \\
\hline PEI & Peine & http://www.landkreis-peine.de/ \\
\hline ROT & Rotenburg & http://www.landkreis-row.de/ \\
\hline RUH & Regionalverband Ruhr & http://www.rvr-online.de/ \\
\hline $\mathrm{SCH}$ & Schaumburg & http://www.schaumburg.de/ \\
\hline SIE & Siegen-Wittgenstein & http://www.siegen-wittgenstein.de/ \\
\hline SOE & Soest & http://www.kreis-soest.de/ \\
\hline SOL & Soltau-Fallingbostel & http://www.soltau-fallingbostel.de/ \\
\hline STA & Stade & http://www.kreis-stade.de/ \\
\hline STE & Steinfurt & http://www.kreis-steinfurt.de/ \\
\hline UEL & Uelzen & http://www.kreis-uelzen.de/ \\
\hline UTR & Utrecht & http://portal.provincie-utrecht.nl/ \\
\hline VER & Verden & http://www.kvhs-verden.de/ \\
\hline WAR & Warendorf & http://www.kreis-warendorf.de/ \\
\hline WES & Wesermarsch & http://www.landkreis-wesermarsch.de/ \\
\hline WIT & Wittmund & http://www.landkreis.wittmund.de/ \\
\hline WOL & Wolfenbüttel & http://www.lk-wolfenbuettel.de/ \\
\hline ZEE & Zeeland & http://www.zeeland.nl/ \\
\hline ZHL & Zuid Holland & http://www.zuid-holland.nl/ \\
\hline
\end{tabular}

\section{References}

Amin, A., \& Thrift, N. (2002). Cities: Reimagining the urban. Cambridge: Polity.

Bauman, Z. (2001). The individualized society. Cambridge: Polity.

Bauman, Z. (2004). Identity: Conversations with Benedetto Vecchi. Cambridge: Polity.

Blokland, T. (2003). Urban bonds. Cambridge: Polity.

Boisen, M., Terlouw, K., \& van Gorp, B. (2011). The selective nature of place branding and the layering of spatial identities. Journal of Place Management and Development 4 (forthcoming).
Boschma, R. A. (2004). The competitiveness of regions from an evolutionary perspective. Regional Studies, 38(9), 1001-1014.

Brenner, N. (2004). New State Spaces: Urban governance and the rescaling of statehood. Oxford: Oxford University Press.

Conroy, M. M., \& Evans-Cowley, J. (2006). E-participation in planning: An analysis of cities adopting on-line citizen participation. Environment and Planning C, 24(3), 371-384.

Cox, K. R. (1999). Ideology and the Growth Coalition. In A. E. G. Jonas \& D. Wilson (Eds.), The urban growth machine: Critical perspectives, two decades later (pp. 21-36). New York: SUNY press. 
Danielzyk, R., \& Wood, G. (2004). Innovative strategies of political regionalization: The case of North Rhine-Westphalia. European Planning Studies, 12(2), 191-207.

Delanty, G., \& Rumford, C. (2005). Rethinking Europe: Social theory and the implications of Europeanization. London: Routledge.

Dijkink, G., \& Winnips, C. (1999). Alternative states: Regions and postfordism rethoric on the internet. GeoJournal, 48(4), 323-335.

Donaldson, A. (2006). Performing regions: Territorial development and cultural politics in a Europe of the Regions. Environment and Planning A, 38(11), 2075-2092.

Ellwein, T. (1993). Der Staat als Zufall und als Notwendigkeit: Die jüngere Verwaltungsentwicklung in Deutschland am Beispiel Ostwestfalen-Lippe. Band 1: Die öffentliche Verwaltung in der Monarchie 1815-1918. Opladen: Westdeutscher Verlag.

Ellwein, T. (1997). Der Staat als Zufall und als Notwendigkeit: Die jüngere Verwaltungsentwicklung in Deutschland am Beispiel Ostwestfalen-Lippe. Band 2: Die öffentliche Verwaltung im gesellschaftlichen und politischen Wandel 1919-1990. Opladen: Westdeutscher Verlag.

ESPON. (2006). Espon database. (www.espon.eu).

Esrock, S. L., \& Leichty, G. B. (2000). Organization of corporate web pages: Publics and functions. Public Relations Review, 26(3), 327-344.

Florek, M., Insch, A., \& Gnoth, J. (2006). City Council websites as a means of place brand identity communication. Place Branding, 2(4), 276-296.

Fortin, A., \& Sanderson, D. (2003). Sites web et identités en région au Québec. Cahiers de Géographie de Québec, 47(131), 263-276.

Harvey, D. (2001). Spaces of capital: Towards a critical geography. Edinburgh: Edinburgh University Press.

Healy, P. (2006). Relational complexity and the imaginative power of strategic spatial planning. European Planning Studies, 14(4), 525-546.

Hinman, L. (2003). Ethics: A pluralistic approach to moral theory. Belmont: Wadsworth.

HL. (1999). 1949-1999 'Landesverband Lippe. Heimatland Lippe, 92(2), 269-300.

Hucker, B. U., Schubert, E., \& Weisbrod, B. (Eds.). (1997). Niedersächsische Geschichte. Göttingen: Wallstein Verlag.

Jeffres, L. W., \& Lin, C. A. (2006). Metropolitan websites as urban communication. Journal of Computer-Mediated Communication, 11(4), 957-980.

Jones, M., \& MacLeod, G. (2004). Regional spaces, spaces of regionalism: Territory, insurgent politics and the English question. Transactions IBG, 29(4), 433-452.

Keating, M. (1998). The new regionalism in Western Europe: Territorial restructuring and political change. Cheltenham: Edward Elgar.

Kitson, M., Martin, R., \& Tyler, P. (2004). Regional competitiveness: An elusive yet key concept? Regional Studies, 38(9), 991-999.

Knottnerus, O. S. (1992). Räume und Raumbeziehungen im Ems Dollart Gebiet. In O. S. Knottnerus, et al. (Eds.), Rondom eems en dollard (pp. 11-42). Groningen/Leer: Schuster Verlag.
Kolbe, L. (2007). Central and Eastern European capital cities: Interpreting www-pages: History, symbols and identity. Planning Perspectives, 22(1), 79-111.

Lagendijk, A., \& Cornford, J. (2000). Regional institutions and knowledge: Tracking new forms of regional development policy. Geoforum, 31(2), 209-218.

MacLeod, G. (2001a). New regionalism reconsidered: Globalization and the remaking of political economic space. International Journal of Urban and Regional Research, 25(4), 804-829.

MacLeod, G. (2001b). Beyond soft institutionalism: Accumulation, regulation, and their geographical fixes. Environment and Planning A, 33(7), 1145-1167.

MacLeod, G., \& Goodwin, M. (1999). Reconstructing an urban and regional political economy: On the state, politics, scale, explanation. Political Geography, 18(6), 697-730.

MacLeod, G., \& Jones, M. (2001). Renewing the geography of regions. Environment and Planning D, 19(6), 669-695.

Massey, D. (2005). For space. London: Sage.

McMillan, S. J. (2000). The microscope and the moving target: The challenge of applying content analysis to the World Wide Web. Journalism and Mass Communication Quarterly, 77, 80-98.

Nauhaus, K.-E. (1984). Das Emsland im Ablauf der Geschichte. Sögel: Emsländische Landschaft.

Niedersachsen. (2007). Niedersachsen: Das Land und seine Regionen. Hannover: Niedersächsisches Landesamt für Statistik.

Niehoff, L. (1995). Vom „Armenhaus Deutschlands“zum Landkreis mit hoher lebensqualität. In G. Müller (Ed.), Emsland (pp. 10-23). Oldenburg: Verlag Komminikation und Wirtschaft.

Noordzij, G. A. (2008). Gelre: Dynastie, land en identiteit in de late middeleeuwen. Leiden.

Paasi, A. (1986). The institutionalisation of regions: A theoretical framework for understanding the emergence of regions and the constitution of regional identity. Fennia, 164(1), 105-146.

Paasi, A. (1996). Territories, boundaries and consciousness: The changing geographies of the Finnish-Russian border. Chichester: Wiley.

Porter, D. R., \& Wallis, A. D. (2002). Exploring Ad Hoc Regionalism. Cambridge MA: Lincoln Institute of Land Policy.

Richter, G. (1995). Die gewerbliche Wirtschaft im Bereich der Industrie- und Handelskammer Lippe zu Detmold. In A. Mayr \& K. Temlitz (Eds.), Bielefeld und Nordost-Westfalen (pp. 283-292). Münster: Geografische Kommission für Westfalen.

Rinne, W. (Ed.). (1993). Landeskunde Nordrhein-Westfalen: Lippe. Paderborn: Verlag Ferdinand Schöningh.

Rodríguez-Pose, A., \& Sandall, R. (2008). From identity to the economy: Analysing the evolution of the decentralisation discourse. Environment and Planning C, 26(1), 54-72.

Savage, M., et al. (2005). Globalization and belonging. London: Sage.

Schuler, T. (2010). Bertelsmann Republik Deutschland: Eine Stiftung macht Politik. Frankfurt am Main: Campus.

Schüpp, H. (1992). Zur Bedeutung der Emsland GmbH für die wirtschaftliche Entwicklung des Emslandes nach 1945. In 
O. S. Knottnerus, et al. (Eds.), Rondom Eems en Dollard (pp. 450-457). Groningen/Leer: Schuster Verlag.

Shelby, T. (2005). We who are dark: The philosophical foundations of black solidarity. Harvard: University Press.

Stich, W. (1998). 90 Jahre Lippischer Heimatbund. Heimatland Lippe, 91, 1-36.

Stinner, J., \& Tekath, K.-H. (Eds.). (2003). Het hertogdom Gelre. Geschiedenis, kunst en cultuur tussen Maas, Rijn en IJssel. Utrecht: Matrijs.

Terlouw, K. (2009). Rescaling regional identities: Communicating thick and thin regional identities. Studies in Ethnicity and Nationalism, 9(3), 452-464.

Terlouw, K. (2010). Charisma and space. Studies in Ethnicity and Nationalism, 10(3), 335-348.
Urban, F. (2002). Small town, big website? Cities and their representation of the internet. Cities, 19(1), 49-59.

Van Houtum, H., \& Lagendijk, A. (2000). Contextualising regional identity and imagination in the construction of polycentric urban regions: The case of the Ruhr area and the Basque country. Urban Studies, 38(4), 747-767.

Weber, M. (1980). Wirtschaft und Gesellschaft: Grundriss der verstehenden Soziologie. Tübingen: Mohr.

Weernicke, J., \& Bultmann, B. (Eds.). (2007). Netzwerk der Macht-Bertelsmann: der medial-politische Komplex aus Gütersloh. Marburg: BdWi-Verlag.

Zijderveld, A. C. (2000). The institutional imperative: The interface of institutions and networks. Amsterdam: Amsterdam University Press. 